\title{
RUBBER CRUMB MODIFIED BITUMEN PRODUCED FROM CRUDE OIL RESIDUALS OF UKRAINIAN DEPOSITS
}

\author{
Andriy Nagurskyy ${ }^{1}{ }^{\otimes}$, Yuriy Khlibyshyn ${ }^{1}$, Oleg Grynyshyn ${ }^{1}$, Victoria Kochubei $^{1}$
}

https://doi.org/10.23939/chcht14.03.420

\begin{abstract}
The main regularities of the modification with a rubber crumb for bitumen produced from the residuals of crude oils of Ukrainian deposits have been studied. The thermal stability of the rubber crumb has been examined using the derivatograpgy. The mechanism of bitumen modification with the rubber crumb at low and high temperatures has been established. The influence of technological factors on the main quality indices of modified bitumen has been studied. The changes in the group composition of the original and modified bitumen were found.
\end{abstract}

Keywords: bitumen, rubber crumb, group composition, derivatography, elasticity, softening point.

\section{Introduction}

Petroleum bitumen is a relatively cheap thermoplastic material used in various industries and everyday life [1]. Most often it is used as a binder for pavement. Asphaltic concrete mixtures are one of the most common road building materials used for the construction of roadways [2]. The quality of bitumen plays a major role in their production. The pavement with bitumen is enough strong, safe and cheaper by 2-2.5 times as compared with concrete. That is why the vast majority of pavements consists of mineral fillers and bitumen, which serves as a strong waterproof binder [3-5]. Apart from road construction, bitumen is used in other industries as a waterproofing material, which is resistant to damage at low temperatures, non-toxic and can be safely used for coatings of different applications.

Mostly, petroleum bitumen does not meet the requirements for modern marketable products. Owing to its nature and thermoplasticity, bitumen does not provide long service life of coatings. The quality of petroleum bitumen mainly depends on characteristics of the raw materials and the production technology. Inconsistent group composition of oil residues and high content of

\footnotetext{
${ }^{1}$ Lviv Polytechnic National University,

12, S. Bandery St., 79013 Lviv, Ukraine

nagurskiy@ukr.net

도 Nagurskyy A., Khlibyshyn Y., Grynyshyn O., Kochubei V., 2020
}

paraffins often cause low quality of bitumen. The problem of road bitumen production is especially urgent at Ukrainian refineries, because they processed mainly lowresin paraffin oils. It is extremely difficult to obtain highquality commercial bitumen from such raw materials, and in some cases it is impossible at all [6]. Bitumen, which is currently being produced at Ukrainian refineries, due to the peculiarities of their production technology, as well as the properties of raw materials, are characterized by insufficient cohesive strength, adhesion and low aging reserve.

The residuals of paraffin oils processing are lowquality raw materials for the production of bitumen. The high content of paraffins reduces elasticity, worsens the low-temperature properties of bitumen, adversely affects the process of obtaining oxidized bitumen, which generally impairs the quality and reduces the durability of all types of bituminous coatings. Instead, it is known that some types of rubber, as well as gum, are used to improve the elastic properties of bitumen and to extend the temperature range of their plasticity. However, the effectiveness of this group of modifiers for bitumen produced from paraffin raw materials remains unexplored. Therefore, the solution of this scientific and practical problem is extremely important for Ukrainian bitumen producers, since most of the petroleum bitumen in Ukraine is obtained from paraffin residuals. The quality of petroleum bitumen, especially road bitumen, is the subject of increasingly stringent requirements. Moreover, the production of paraffin, high-paraffin and high-viscosity heavy crude oils is increasing. The processing of such oils does not always allow to obtain high-quality petroleum bitumen and, therefore, the modification of bitumen is necessary [7].

Bitumen is called modified bitumen, when its properties are improved by addition of certain substances (polymers, rubber crumb, sulfur, adhesive additives, etc.). Bitumen with the addition of polymers is called polymerbitumen binders (PBB); with the addition of raw rubber bitumen-raw rubber binders (BRB), with the addition of crumb rubber - rubber-bitumen binders (RBB). [8]

The most promising direction in improving the quality of bitumen for pavement and roofing coatings is the bitumen modification with synthetic polymeric materials 
[9-10]. Polymers give a wide opportunity to regulate the quality of received bitumen [11]. In Europe the volume of polymer modified bitumen (PMB) production is more than $10 \%$ of the total amount of bitumen used [12]. For the modification of bitumen, the following types of polymers are used: elastomers (raw rubber, rubber crumb); thermoplastics (polyethylene, polypropylene, polyvinyl chloride, etc.); thermoplastic elastomers (styrene-butadienestyrene, ethylene vinyl acetate, ethylene-propylene-diene copolymer, etc.) [13]; thermosetting polymers (epoxy resins, polyurethane resins, etc.). Today thermoplastics and thermoplastic elastomers are most often used for bitumen production [11]. In addition to polymers, sulfur, petroleum polymer resins and many other substances may also be used [14-16].

One of the promising directions for modifying bitumen is the use of rubber crumb [3, 17-18], which is one of the most widespread waste products today. Its advantages as a modifier for bitumen production are: low cost, the stability of the resulting modified bitumen to cracking, aging and low temperatures, the solution of the problem of automobile tires and other waste rubber products utilization. Rubber crumb modified bitumen, which is used for road construction, allows to reduce the noise level of riding cars.

However, the process of modification with elastomers for bitumen produced from the residuals of paraffin oils of Ukrainian deposits is under development today. Therefore, it was necessary to study the basic regularities of this process, using different types of modifiers, and to establish the possibility and feasibility of such modification on an industrial scale.

\section{Experimental}

The initial material was a construction petroleum bitumen BNB70/30, obtained from high-paraffin crude oil of Ukrainian deposits, with the following characteristics: softening point is $355 \mathrm{~K}$; ductility at $298 \mathrm{~K}$ is $2 \mathrm{~cm}$; Penetration at $298 \mathrm{~K}$ is $17 \cdot 0.1 \mathrm{~mm}$; elasticity is $50 \%$.

To carry out derivatographic analysis and modification of bitumen, we used a rubber crumb which was obtained by crushing waste tires.

The thermographic studies of the rubber crumb were carried out using derivatograph Q-1500 D of PaulikPaulik-Erdey system with the registration of the analytical signal. The samples were analyzed under dynamic mode with a heating rate of $10 \mathrm{~K}$ per minute in an atmosphere of air and argon. The sample weight was $200 \mathrm{mg}$. The reference substance was $\mathrm{Al}_{2} \mathrm{O}_{3}$.

The swelling and dissolution of the rubber crumb was carried out on a laboratory setup. Pre-weighed samples of the rubber crumb and test medium were loaded into a metal container and heated in electric oven at a given temperature during a predetermined interval of time under constant stirring. Then the undissolved rubber crumb was separated from the medium using a metal sieve, weighed and compared with the original weight of rubber crumb.

The modified bitumen was also prepared on a laboratory setup. Pre-weighed samples of the initial components were loaded into a metal container and heated in an electric oven at a given temperature during a predetermined interval of time under constant stirring.

To determine the gel fraction content, a preweighed sample of rubber crumb was loaded into glass ampoules closed on both sides with a metal mesh. The ampoules were immersed in the test medium and kept at 423 or $523 \mathrm{~K}$ for $1-9 \mathrm{~h}$ under constant stirring. Then the ampoules were removed and the crumb was extracted by benzene in the Soxhlet apparatus for $8 \mathrm{~h}$. The undissolved crumb was dried in a drying cabinet and weighed on an analytical grade. The gel fraction content (GC, \%) was determined by the formula:

$$
G C=\frac{m_{1}}{m_{0}} \cdot 100
$$

where $m_{0}$ is the initial weight of the rubber crumb, $\mathrm{g} ; m_{1}$ is the crumb weight after extraction, $\mathrm{g}$.

The softening point ( $R \& B$ method), penetration, elasticity and group composition were determined for the modified bitumen in accordance with the standard procedures [19-21].

\section{Results and Discussion}

It is known that rubber is a vulcanizate of raw rubber in the form of three-dimensional structure under normal conditions. This structure, in our opinion, cannot dissolve in bitumen, or its separate components at low temperatures. When rubber is heated to high temperatures, the destruction of three-dimensional structure followed by dissolution of formed linear fragments in bitumen is possible. That is why the temperature is a decisive technological factor when modifying bitumen with the rubber crumb.

In order to confirm or refute the proposed hypotheses on the behavior of the rubber crumb during the bitumen modification, it was necessary to determine the effect of temperature on the rubber crumb. For this purpose, a derivatographic analysis of the rubber crumb in various media was carried out.

When choosing a medium, the following considerations were taken into account. The medium of argon (inert medium) simulates the process of rubber crumb thermal transformation without air (when a piece of rubber crumb is in a bitumen volume). The air medium simulates the thermal transformation of rubber crumb particles which are located on the surface and contact with air oxygen. 
The thermograms of the samples in the air and inert media are shown in Figs. 1 and 2, respectively. The comparison of thermogravimetric curves is represented in Fig. 3.

The small weight losses of the samples heated in the air and inert atmosphere in the temperature range of 293 $419 \mathrm{~K}$, which are accompanied by the appearance of shallow endothermic effects on the DTA curve corresponds to the separation of residual volatiles contained in the structure of rubber. The exothermic effect on the DTA curve in the temperature range of 413-493 K appears due to the number of processes. In this temperature range, the destruction of the long-chain sulfur residues contained in the rubber and additional cross-linking of the rubber molecules by monomeric sulfur with respect to free unsaturated bonds are possible, i.e., the additional vulcanization of the rubber with the structure packing.

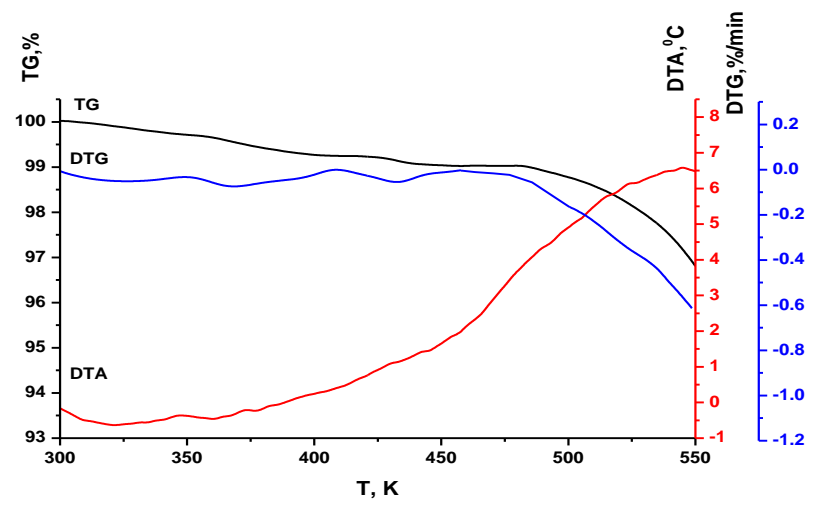

Fig. 1. Thermogram of the rubber crump in the air medium

Fig. 3. Comparison of the rubber crump thermograms in different media
A more significant weight loss is observed for the sample heated in the air, which may indicate a partial oxidation of free sulfur and its release as $\mathrm{SO}_{2}$ (Fig. 3). At the temperatures above $483 \mathrm{~K}$ the intense weight loss accompanied by the exoeffect on the DTA curve is observed corresponding to the beginning of deep destructive and thermooxidative processes. The beginning of the thermal destruction of the sample heated in the argon medium is shifted to the region of higher temperatures, indicating a higher thermal stability of the sample (Fig. 3, Table 1).

Thus, it was established that the process of rubber thermal devulcanization in the air medium begins after heating to $483 \mathrm{~K}$, and in the inert gas medium - after heating to $493 \mathrm{~K}$. A high rate of this process is observed within $523-543 \mathrm{~K}$.

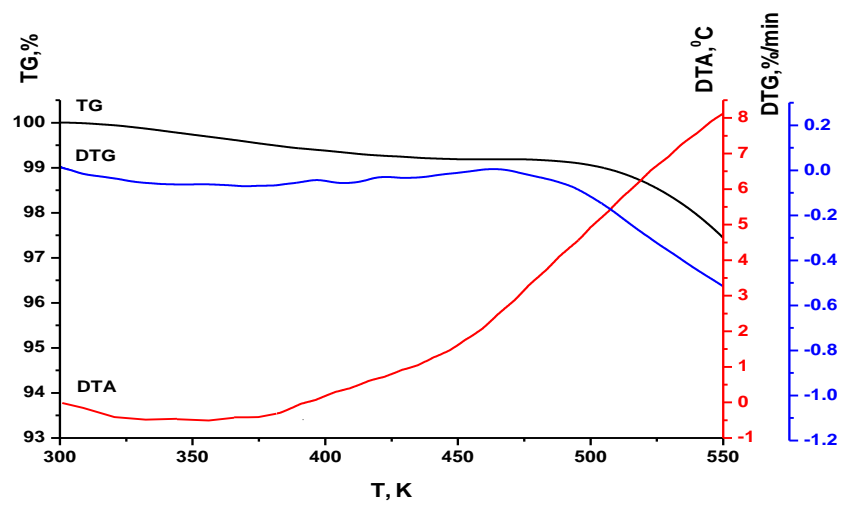

Fig. 2. Thermogram of the rubber crump in the inert gas (argon) medium

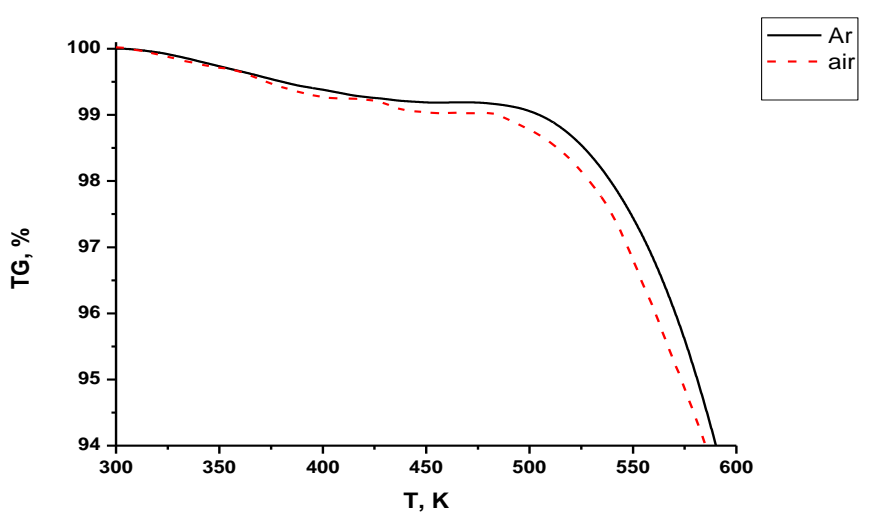

Table 1

Results of thermal analysis of rubber crumb samples

\begin{tabular}{|c|c|c|c|}
\hline Medium & Temperature range, $\mathrm{K}$ & Weight loss, \% & Thermal effect \\
\hline \multirow{3}{*}{ Air } & $293-413$ & 0.75 & endo \\
\cline { 2 - 4 } & $413-483$ & 0.24 & exo \\
\cline { 2 - 4 } & $483-548$ & 2.01 & exo \\
\hline \multirow{3}{*}{ Inert gas (argon) } & $293-419$ & 0.72 & endo \\
\cline { 2 - 4 } & $419-493$ & 0.17 & exo \\
\cline { 2 - 4 } & $493-548$ & 1.55 & exo \\
\hline
\end{tabular}


Since the rubber crumb, getting into the bitumen medium during modification in a certain way interacts with its components, it is important to establish, firstly, the nature of this interaction, and secondly, how the modification conditions (temperature, time, etc.) affect it.

To our mind, when bitumen is modified with the rubber crumb, the processes of rubber crumb swelling, as well as its partial or complete dissolution in bitumen occur. To check and confirm the correctness of the mechanism of the action, the dissolution of the rubber crumb in the bitumen medium was studied. The process of swelling and dissolution of the rubber crumb in bitumen was studied at 423 and $523 \mathrm{~K}$ for $9 \mathrm{~h}$. The experimental results are shown in Fig. 4.

At the first stage there is a swelling of the rubber crumb due to the absorption of some oil components contained in bitumen. Then the rubber crumb weight decreases, which indicates its gradual dissolution in bitumen. During the first hour of modification there is a sharp increase in the weight of rubber crumb. The most effective dissolution takes place during the first five hours. The rate of further dissolution sharply decreases, which is confirmed by the obtained data.

The gel fraction content decreases with the increase in dissolution time (Fig. 5), indicating the proceeding of devulcanization process and resin dissolution in the medium of bitumen.

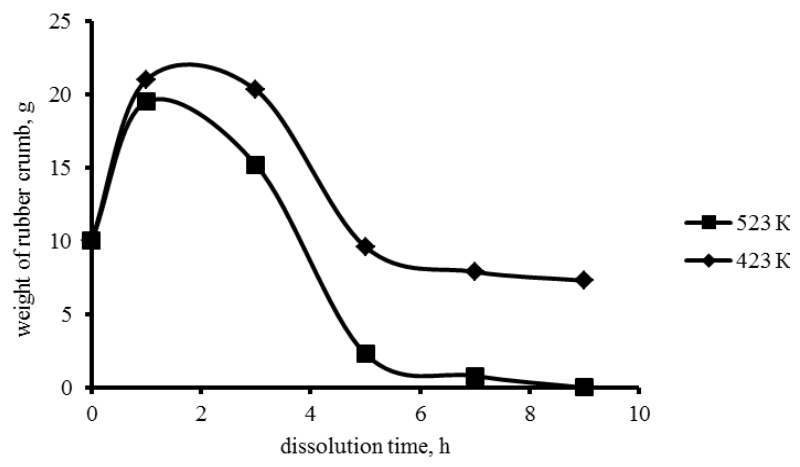

Fig. 4. Rubber crumb weight vs. dissolution time in bitumen BNB 70/30

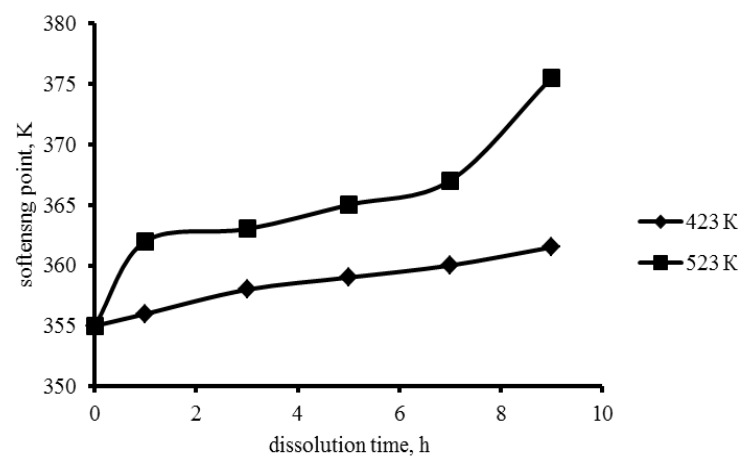

Fig. 6. Softening point of modified bitumen BNB 70/30 vs. dissolution time
Next step was to investigate the effect of time on the main operational properties of modified bitumen. For this purpose the BNB-70/30 bitumen (fraction of $2.0 \mathrm{~mm}$ ) was modified with the rubber crump $(10 \mathrm{wt} \%)$. The process was carried out at low $(423 \mathrm{~K})$ and high temperatures $(523 \mathrm{~K})$. The results are shown in Figs. 6-8.

It was established (Fig. 6) that the softening point of modified bitumen increases with the increase in dissolution time. Moreover, the effect at high temperatures is much higher, which is in agreement with the previous results.

Penetration of the modified bitumen decreases with the increase in dissolution time (Fig. 7), i.e., the hardness of bitumen increases. The difference in values at low and high temperatures is also related to the principal difference in the mechanisms of bitumen modification at different temperatures.

The elasticity of modified bitumen during the dissolution of the rubber crumb at low temperatures slightly increases (Fig. 8). Instead, when a similar amount of rubber crumb is dissolved in bitumen at high temperatures, there is a sharp increase in elasticity associated with the dissolution of devulcanized rubber fragments in bitumen.

The obtained results confirm the correctness of the proposed mechanism for modifying bitumen with the rubber crumb.

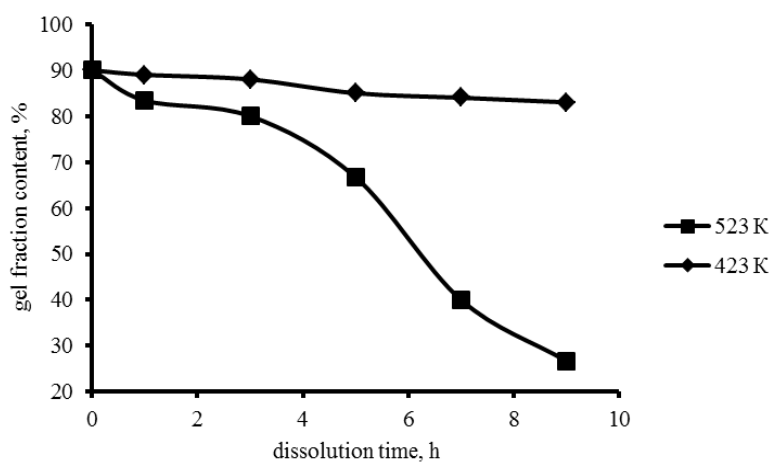

Fig. 5. Gel fraction content $v s$. dissolution time in bitumen BNB 70/30

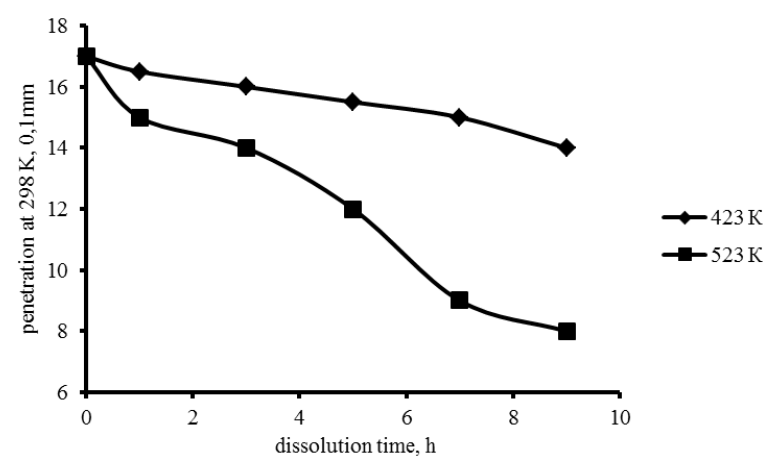

Fig. 7. Penetration of modified bitumen BNB 70/30 vs. dissolution time 


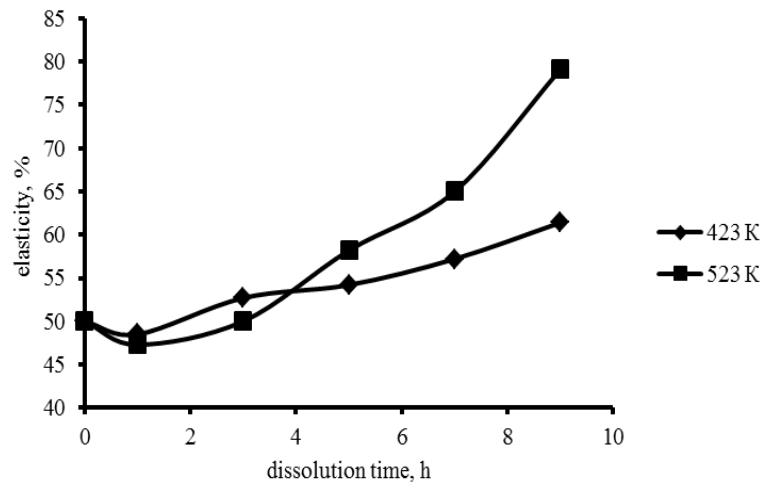

Fig. 8. Elasticity of modified bitumen BNB 70/30 vs. dissolution time

Table 2

Group composition of bitumen BNB 70/30 modified with the rubber crumb

\begin{tabular}{|c|c|c|c|}
\hline \multirow{2}{*}{ Group composition, wt \% } & \multicolumn{3}{|c|}{ Content of the rubber crump in bitumen, wt \% } \\
\cline { 2 - 4 } & \multicolumn{2}{|c|}{5} & 5 \\
\hline & \multicolumn{3}{|c|}{ Modification temperature 423 K } \\
\hline Asphaltenes & 23.62 & 25.00 & 27.06 \\
\hline Resins & 24.97 & 27.40 & 29.35 \\
\hline Oils & 51.37 & 47.00 & 43.10 \\
\hline Carbenes and carboids & 0.04 & 0.60 & 0.49 \\
\hline Asphaltenes & Modification temperature 523 K & 21.47 \\
\hline Resins & 23.62 & 22.49 & 29.44 \\
\hline Oils & 24.97 & 27.26 & 48.73 \\
\hline Carbenes and carboids & 51.37 & 50.12 & 0.36 \\
\hline
\end{tabular}

So, when introducing the rubber crumb into bitumen, almost all its characteristics are changed, in particular, the softening point and elasticity increase, penetration and ductility decrease. Such changes in the bitumen properties, obviously, are associated with the changes in its group composition. Therefore, it was necessary to determine the group composition of the original bitumen and bitumen modified with the rubber crumb. The results of the studies are shown in Table 2.

When using the rubber crumb to modify bitumen at low temperature $(423 \mathrm{~K})$, the content of resins and asphaltenes increases, and the content of oils decreases in comparison with unmodified bitumen. The content of oils decreases because some part of the oils dissolves in the rubber crumb during its swelling and is separated together with the rubber crumb on the metal sieve. With the increase in the amount of rubber crumb in bitumen from 0 to $10 \mathrm{wt} \%$ the content of asphaltenes and resins increases by 3.44 and $4.38 \mathrm{wt} \%$, respectively; the content of oils is reduced by $8.27 \mathrm{wt} \%$.

The results concerning the number of carbenes and carbides are approximate because small particles of rubber crumb, not separated by a metal sieve, may remain in the modified bitumen.
When bitumen is modified with the rubber crumb at high temperature $(523 \mathrm{~K})$, the group composition varies in a different way. There is an increase in the content of resins and a decrease in the content of asphaltenes and oils. This change in group composition is due to the fact that at high temperature the rubber is devulcanized. The resultant linear fragments are mainly included in the group of resins and small part of them - in the group of oils.

Due to the decrease in the amount of oil components and the increase in the content of resins and asphaltenes, an appropriate change in the operational properties of the modified bitumen is observed (Figs. 6-8). This change is correlated with the change in a group composition and is somewhat predictable. Due to the reduction of oils content in the modified bitumen its infusibility increases, which is characterized by the softening point. The increased total content of resins and asphaltenes leads to the increase in bitumen hardness (characterized by its penetration), as well as to the decrease in its ductility. The increase in resins content results in the increased elasticity of modified bitumen. Thus, the rubber crumb as a modifier, changes the group composition of the petroleum bitumen, and as a result, its operational characteristics. 


\section{Conclusions}

The mechanism of bitumen modification with the rubber crumb was studied. When modifying petroleum bitumen with the rubber crumb at low temperatures (433$453 \mathrm{~K}$ ), the main phenomenon that accompanies the modification is the swelling of rubber crumb due to the absorption of some oil components. This fact leads to the changes in the group composition of bitumen and its properties, in particular, the softening point increase and the penetration decrease. When bitumen is modified at high temperatures (493-523 K), a partial or complete devulcanization of rubber occurs. The resulting linear fragments are soluble in bitumen, changing its properties. As a result of this modification, the softening point increases and penetration decreases, but the main positive effect is a significant increase in the elasticity of the modified bitumen.

A change in the group composition of bitumen BNB-70/30 was studied after its modification with the rubber crumb. It was established that at low temperatures, with the increase in the amount of rubber crumb the content of resins and asphaltenes increases, and the content of oil components decreases. At high temperatures only the content of resins increases, and the content of oil components and asphaltenes decreases.

\section{References}

[1] Gun R.: Neftianye Bitumy. Khimia, Moskva 1973.

[2] Kotov S., Tyshchenko V., Rudiak K. et al.: Mir Nefteproduktov, 2008, 4, 14.

[3] Grigoryeva O., Starostenko O., Fainleib A. et al.: Chem. Chem. Technol., 2012, 6, 59.

[4] Pyshyev S., Gunka V., Grytsenko Y., Bratychak M.: Chem. Chem. Technol., 2016, 10, 631.

https://doi.org/10.23939/chcht10.04si.631

[5] Kavalov G.: Avtomobil. Dorogi, 2006, 6, 17.

[6] Fryder I., Pysh'yev S., Grynyshyn O.: Chem. Chem. Technol., 2013, 7, 105. https://doi.org/10.23939/chcht07.01.105

[7] Bratychak M., Chervinskyy T., Astakhova O., Shyshchak O.: Chem. Chem. Technol., 2010, 4, 325.

[8] Astakhova O., Shved M., Zubal O. et al.: Chem. Chem. Technol., 2019, 13, 112. https://doi.org/10.23939/chcht13.01.112

[9] Xie J.-X., Sun C.-Y., She Y.-C. et al.: Acta Petrolie Sinica (Petrol. Process. Sec.), 2008, 24, 74.

http://www.syxbsyjg.com/EN/Y2008/V24/I1/74
[10] Masson J-F., Collins P., Woods J. et al.: [in:] Polymer Modified Bitumen. Properties and Characterisation.

Woodhead Publ. Ser. in Civil and Structural Engineering 2011, 298-335. https://doi.org/10.1533/9780857093721.2.298

[11] Pyshyev S., Gunka V., Grytsenko Y. et al.: Int. J. Pavement Res. Technol., 2017, 10, 289.

https://doi.org/10.1016/j.ijprt.2017.05.001

[12] Zolotariov V., Simonov A.: Avtoshliakhovyk Ukrainy, 2001, 3, 32.

[13] Nagurskyy A, Khlibyshyn Y., Grynyshyn O.: Chem. Chem. Technol., 2017, 11, 226. https://doi.org/10.23939/chcht11.02.226 [14] Nykulyshyn I., Pikh Z., Gnatush S. et al.: East-Eur. J. Adv. Technol., 2016, 2, 31.

[15] Gnativ Z., Rypka A., Nykulyshyn I. et al.: Chem. Chem. Technol., 2014, 8, 401. https://doi.org/10.23939/chcht08.04.401

[16] Khlibyshyn Yu., Pochapska I., Grynyshyn O., Gnativ Z.: Vopr. Khim. Khim. Technol., 2018, 5, 161.

[17] Rudenskyy A., Khromov A., Mariev V.: Dorogi Rosii XXI veka, 2004, 5, 62 ..

[18] Shikhaliev K., Ibragimova S., Bafadarova Z. et al.: Izv. Vuzov Azerbajdzhana, 2008, 6, 29.

[19] Nefteprodukty. Metody Ispytaniy. https://files.stroyinf.ru/Index2/1/4294746/4294746383.htm [20] BS EN 1426:2000. European Standard. Bitumen and bituminous binders. Methods of tests for petroleum and its products. Determination of needle penetration.

[21] BS EN 1427:2007. European Standard. Bitumen and bituminous binders. Determination of the softening point. Ring and Ball method.

Received: April 22, 2019 /Revised: June 12, 2019/ Accepted: August 28, 2019

\section{МОДИФІКУВАННЯ БІТУМІВ ОТРИМАНИХ З ЗАЛИШКІВ ПЕРЕРОБКИ НАФТ УКРАЇНСЬКИХ РОДОВИЩ ГУМОВОЮ КРИХТОЮ}

Анотація. Наведено результати досліджень основних закономірностей прочесу модифікування бітумів, одержаних з залишків переробки нафт українських родовищ гумовою крихтою. Вивчено термічну стійкість гумової крихти дериватографічним методом. Встановлено механізм модифікування бітумів гумовою крихтою за низьких та високих температур. Вивчено вплив технологічних чинників на основні показники якості отриманих модифікованих бітумів. Вивчено зміну групового складу вихідного бітуму і бітуму модифікованого гумовою крихтою.

Ключові слова: бітум, гумова крихта, груповий склад, дериватографічні дослідження, еластичність, температура розм'якшення. 